\title{
PERTUMBUHAN IKAN SEMAH (Tor tambra, Valenciennes, 1842) DI PERAIRAN SUNGAI MUSI, SUMATERA SELATAN
}

\author{
Subagja, Arif Wibowo, dan Marson \\ Peneliti pada Balai Riset Perikanan Perairan Umum, Mariana-Palembang \\ Teregristrasi I tanggal: 16 Maret 2009; Diterima setelah perbaikan tanggal: 17 Maret 2009; \\ Disetujui terbit tanggal: 19 Maret 2009
}

\begin{abstract}
ABSTRAK
Tujuan penelitian adalah untuk mengetahui pertumbuhan ikan semah (Tor tambra) di perairan Sungai Musi, Sumatera Selatan. Penelitian ini dilakukan selama Maret-Agustus 2008 di habitat ikan tersebut di perairan Sungai Musi, Sumatera Selatan. Lokasi penelitian ditentukan secara purposive sampling. Contoh ikan dari hasil tangkapan nelayan disimpan dalam kantong berisi alkohol $75 \%$ dan diberi label. Panjang total ikan diukur dengan menggunakan digital caliper yang memiliki ketelitian $0,01 \mathrm{~mm}$. Bobot ikan ditimbang dengan timbangan manual dengan ketelitian 0,1g. Sebanyak 34 contoh ikan dianalisis pertumbuhannya dengan menggunakan persamaan Von Bertalanffy yang kemudian diestimasi dengan Elevan. Metode Battacharya digunakan untuk penentuan kelompok umur dan hubungan panjang bobot ikan. Hasil penelitian memperlihatkan bahwa ikan semah di perairan Sungai Musi memiliki pola pertumbuhan allometrik. Panjang ikan ketika lahir $(t=0)$ diestimasi $21,44 \mathrm{~mm}$ dan bobotnya $0,645 \mathrm{~g}$. Ikan semah daerah ini tidak bertambah panjang dan bobotnya masing-masing setelah mencapai 6 dan 5,5 tahun. Masa pertumbuhan bobot ikan yang cepat diperkirakan terjadi pada saat ikan berumur 1-3 tahun.
\end{abstract}

\section{KATAKUNCI: pertumbuhan, ikan semah, Tor tambra, Sungai Musi}

\section{PENDAHULUAN}

Ikan dari genus Tortergolong jenis ikan endemik yang mendiami perairan sungai dan danau di bagian hulu. Penyebarannya adalah di Paparan Sunda yang meliputi di Indonesia (Jawa, Sumatera, dan Kalimantan, Weber \& de Beaufort, 1962) dan Thailand (Smith, 1945). Di Sumatera Selatan dan Jambi, ikan ini dikenal dengan nama semah dan ditemui di perairan danau (Danau Ranau dan Kerinci) dan sungai (Sungai Musi dan Batanghari bagian hulu-pegunungan). Habitatnya adalah perairan yang mengalir dengan substrat dasar perairan berbatu atau berkerikil. Anakan ikan ditemukan di perairan yang dangkal dan ikan dewasa ditemukan di cekungan sungai yang dalam (lubuk). Jenis ikan ini di habitatnya mempunyai nilai ekonomis tinggi sebagai ikan konsumsi. Menurut Kottelat et al. (1993), ikan semah sudah terancam punah. Selanjutnya, ikan semah telah dilindungi secara tradisional, karena alasan budaya dan nilai penting sebagai makanan di berbagai daerah di Indonesia (Sabar, 1983; Rachmatika, 1992). Pengelolaan sumber daya ikan semah membutuhkan data aspek biologi, antara lain makanan, reproduksi, dan pertumbuhan.

Makanan utama ikan semah adalah diatom, algae, dan makrofita (Sulastri et al., 1985). Menurut Rupawan et al. (1999), ikan semah (T. douronensis) di Danau Kerinci dan Sungai Merangin-Jambi bersifat omnivous dengan makanan utamanya berupa buah-buahan
$(38,5 \%)$, moluska $(29,7 \%)$, detritus $(16,9 \%)$, dan serangga air (12,7\%).

Ikan semah melakukan migrasi ke hilir sungai pada saat musim hujan dan memiliki tingkat reproduksi yang rendah (Kottelat et al., 1993). Ikan semah betina telah matang gonad pada kisaran panjang 48,8-64,8 $\mathrm{cm}$ dengan jumlah telur 11.689-14.443 butir (Rupawan et al., 1999). Pada kondisi budidaya, ikan semah dapat berkembang gonadnya dengan pemberian pakan buatan berkadar protein 30 - 45\% (Hardjamulia et al., 1999).

Data dan informasi mengenai umur dan pertumbuhan ikan dapat memberikan informasi tentang produksi suatu jenis ikan (Effendie, 1997; Tesch, 1971) dan sangat penting untuk manajemen sumber daya perikanan (Lagler et al., 1977). Namun, data tersebut untuk ikan semah di perairan Musi belum tersedia. Oleh karena itu, suatu penelitian bertujuan untuk mengetahui pertumbuhan ikan semah di perairan Musi, Sumatera Selatan telah dilakukan. Hasil penelitian ini diharapkan dapat memberikan manfaat bagi pengembangan sumber daya ikan semah khususnya di perairan Sungai Musi, Sumatera Selatan.

\section{BAHAN DAN METODE}

Penelitian ini dilakukan selama Maret - Agustus 2008 di perairan Sungai Musi, Sumatera Selatan. 


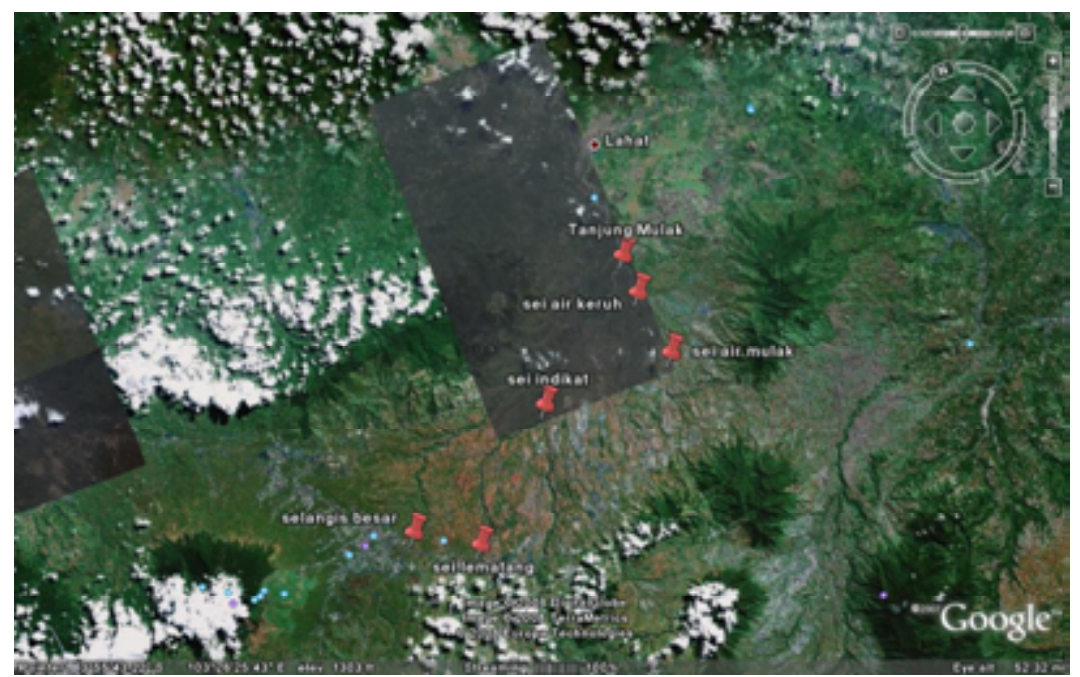

Gambar 1. Peta lokasi penelitian (Sumber: www.googlemap.com).

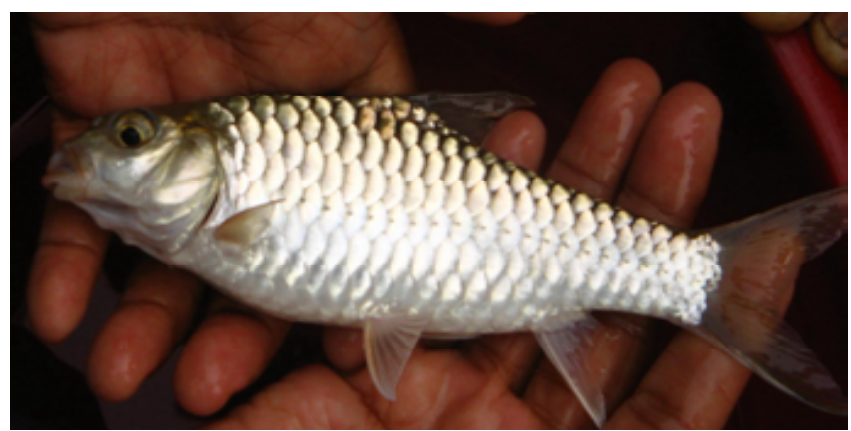

Gambar 2. Ikan semah (T. tambra, Valenciennes, 1842).

Stasiun penelitian ditentukan secara purposive sampling, yaitu di bagian perairan Musi yang terletak di Kabupaten Lahat, Provinsi Sumatera Selatan (Gambar 1). Perairan yang dipilih adalah anak sungai yang bermuara di Sungai Musi, yaitu secara berturutturut dari bagian atas ke bawah: Sungai Tanjung Mulak, Sei Air Keruh, Sei Air Mulak, Sei Indikat, Selangis Besar, dan Lematang.

Contoh ikan semah diperoleh dari hasil tangkapan nelayan di sekitar stasiun penelitian (Gambar 2). Ikan contoh tersebut diukur panjang total dan bobotnya. Pengukuran panjang total ikan dilakukan dengan menggunakan digital caliper yang memiliki ketelitian sampai dengan 0,01 mm, di bagian sisi sebelah kiri tubuh ikan. Bobot ikan ditimbang dengan timbangan manual dengan ketelitian $0,1 \mathrm{~g}$.

Pertumbuhan ikan diduga dengan menggunakan persamaan Von Bertalanffy (Sparre \& Venema, 1999). Persamaan pertumbuhan von Bertalanffy (VB) telah digunakan secara luas untuk mendeskripsikan pola sejarah hidup dari pertumbuhan somatik pada ikan dan organisme lainnya yang menunjukkan pertumbuhan yang tidak atau sulit ditentukan (Ricker, 1975). Persamaan Von Bertalanffy yang digunakan sebagai berikut:

$$
\mathrm{L}_{\mathrm{t}}=\mathrm{L}_{\text {maks }}\left(1-\mathrm{e}^{-\mathrm{K}(\mathrm{t}-\mathrm{t} \mathrm{o})}\right)
$$

di mana:

$\mathrm{L}_{\mathrm{t}} \quad$ = panjang ikan pada umur ke-t $(\mathrm{mm})$

$\mathrm{L}_{\text {maks }}=$ panjang maksimal $(\mathrm{mm})$

$\mathrm{K}^{\prime}=$ koefisien pertumbuhan

$\mathrm{t}_{\mathrm{o}}=$ umur hipotesis ikan pada saat nol tahun

Nilai $L_{\text {maks }}$ dan $\mathrm{K}$ didapatkan dari hasil penghitungan dengan metode ELEFAN 1 yang terdapat dalam program FISAT.

Nilai $\mathrm{t}$ dapat dihitung dari rumus empiris Pauly (Pauly, 1988), yaitu:

$$
\log -\left(t_{0}\right)=-0,3922-0,2752 \log L_{,}-1,038 \log K \ldots . . .(2
$$

Frekuensi panjang ikan dihitung dengan membuat interval kelas. Jumlah dan interval selang kelas dihitung dengan menggunakan rumus sebagai berikut: 
$\mathrm{SK}=1+3,32 \log N$

$\mathrm{JK}=($ Pmaks $-\mathrm{Pmin}) / \mathrm{SK}$

di mana:

SK = selang kelas panjang ikan

$\mathrm{N} \quad=$ jumlah atau banyaknya ikan (ekor)

$\mathrm{JK} \quad=$ jumlah kelas

Pmaks $=$ panjang maksimum ikan $(\mathrm{mm})$

Pmin $=$ panjang minimum ikan $(\mathrm{mm})$

Kelompok umur ikan semah yang tertangkap ditentukan berdasarkan pada metode Battacharya dengan menggunakan progam FISAT. Pada dasarnya metode Bhattacharya adalah suatu teknik memisahkan data sebaran frekuensi panjang ke dalam beberapa distribusi normal (sebaran normal) dan distribusi total. Penentuan distribusi normal ini dimulai dari sebaran kiri distribusi total, kemudian bergerak ke kanan selama ada distribusi normal yang dapat dipisahkan dari distribusi total (Sparre \& Venema, 1999).

Puncak dari masing-masing distribusi normal merupakan modus frekuensi panjang, disebut kelompok umur (kohort). Kemudian kelompok umur ini akan bergerak ke kanan, dengan kata lain kelompok umur itu bertambah panjang atau tumbuh. Kurva distribusi normal tiap kelompok umur mempunyai persamaan berikut:

$$
F c(x)=\frac{n d l}{s \sqrt{2 p i}} \exp \left[\frac{-(x-\bar{x})^{2}}{2 s^{2}}\right]
$$

di mana:

$$
\begin{aligned}
& \mathrm{n}=\text { jumlah populasi } \\
& \mathrm{dl}=\text { lebar selang kelas } \\
& \mathrm{s}=\text { simpangan baku } \\
& \mathrm{x}=\text { nilai tengah kelompok umur }
\end{aligned}
$$

Pertumbuhan bobot ikan diduga dengan menggunakan persamaan Von Bertalanffy. Hubungan panjang-bobot ikan ditentukan berdasarkan pada persamaan sebagai berikut (Sparre \& Venema, 1999):

$$
W_{t}=W_{\infty} \quad\left(1-e^{-k(t-t o)}\right)^{b}
$$

di mana:

$$
\begin{array}{ll}
\mathrm{W}_{\mathrm{t}} & =\text { bobot ikan pada umur ke-t }(\mathrm{mg}) \\
\mathrm{W}_{\infty} & =\text { bobot ikan maksimum }(\mathrm{mg}) \\
\mathrm{k} & =\text { koefisien pertumbuhan }\left(\mathrm{t}^{-1}\right) \\
\mathrm{t}_{\mathrm{o}} & =\text { umur hipotesis ikan pada nol tahun }
\end{array}
$$

Nilai $\mathrm{L}_{\text {, dan }} \mathrm{k}$ didapatkan dari hasil penghitungan dengan metode ELEFAN 1 yang terdapat dalam program FISAT. Nilai $t_{0}$ dapat dihitung dari rumus empiris Pauly (Pauly, 1988) sebagai berikut:

$$
\log -\left(t_{0}\right)=-0,3922-0,2752 \log L_{,}-1,038 \text { Log } k \text {..... (7 }
$$

Hubungan panjang bobot ikan ditentukan berdasarkan pada uji regresi dengan rumus sebagai berikut (Tesch, 1971):

$$
\mathrm{W}=\mathrm{a} \mathrm{L}^{\mathrm{b}}
$$

di mana:

$$
\begin{array}{ll}
\mathrm{W} & =\text { berat tubuh ikan }(\mathrm{g}) \\
\mathrm{L} & =\text { panjang ikan }(\mathrm{mm}) \\
\mathrm{a} \text { dan } \mathrm{b} & =\text { konstanta }
\end{array}
$$

Bentuk transformasi logaritmiknya adalah Log $W=\log a+b \log L$ untuk mendapatkan tingkat pertumbuhannya ( $\mathrm{b}=$ slope). Menurut Lagler et al. (1977), nilai b berkisar 2,5 - 4,0, namun berkisar dekat 3. Jika $b<3$ berarti pertumbuhan panjang lebih cepat daripada pertumbuhan bobotnya. Jika $b=3$, pertumbuhan bobot seimbang dengan pertumbuhan panjang, disebut isometrik (Ricker dalam Effendie, 1979).

\section{HASIL DAN BAHASAN}

\section{Hasil}

Jumlah contoh ikan semah yang diperoleh dan dianalisis adalah 34 ekor. Jumlah contoh yang sedikit menyebabkan sebaran frekuensi panjang tidak menyebar secara merata (Gambar 3). Pendugaan parameter pertumbuhan $\left(k, t_{0}\right.$, dan $L_{\text {, }}$ ) ikan semah (Gambar 4). Parameter pertumbuhan tersebut adalah $L "=215.25 ; k=0,180$ dan $t_{0}=-0,583$. Persamaan pertumbuhan ikan semah menjadi $\mathrm{Lt}=215,25\left(1-\mathrm{e}^{-}\right.$ $0,18(++0,583)$. Ikan semah memiliki 3 kelompok umur berdasarkan pada ukuran panjangnya (L), yaitu 88,71 ; 140; dan $184 \mathrm{~cm}$. Grafik pertumbuhan panjang ikan semah tersebut dapat dilihat pada Gambar 5.

Gambar 6 dan 7 masing-masing menunjukkan hubungan panjang bobot Ikan semah dan model pertumbuhannya yang berbasiskan bobot. Parameter pertumbuhan hasil perhitungan adalah Wmaks $=43,58$, $\mathrm{k}=0,160$ dan $\mathrm{t}_{0}=-1.764$. Persamaan pertumbuhan ikan semah tersebut menjadi $\mathrm{Wt}=43,58\left(1-\mathrm{e}^{-0,18(t+0,583}\right)^{3,0028}$.

\section{Bahasan}

Panjang asimtotik $\left(\mathrm{L}_{\text {, }}\right)$ ikan semah berkisar 215,25 $\mathrm{cm}$. Ikan semah di perairan Musi diperkirakan akan mendekati panjang asimtotiknya pada umur 6 tahun. Kecepatan mencapai panjang asimtotik tersebut 


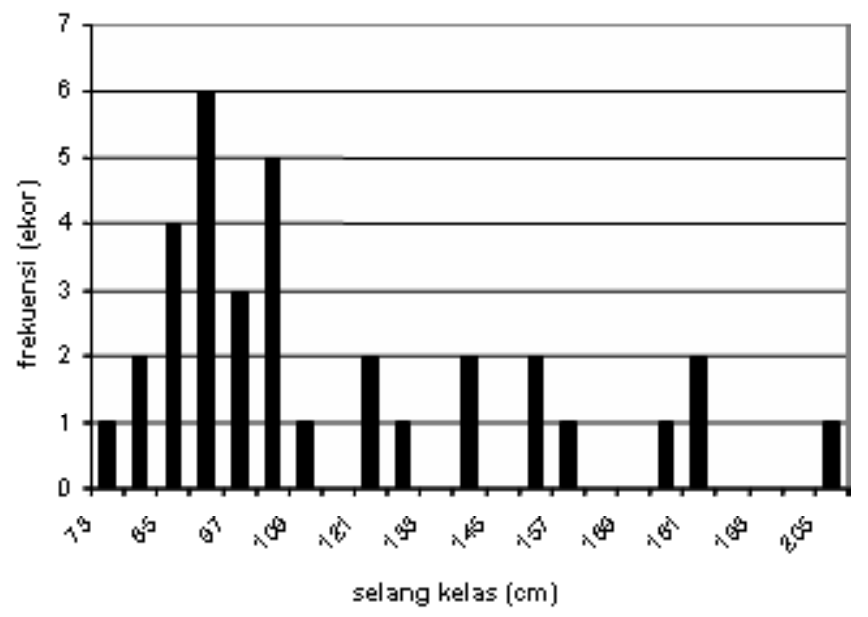

Gambar 3. Sebaran panjang total ikan semah di perairan Musi, Sumatera Selatan.

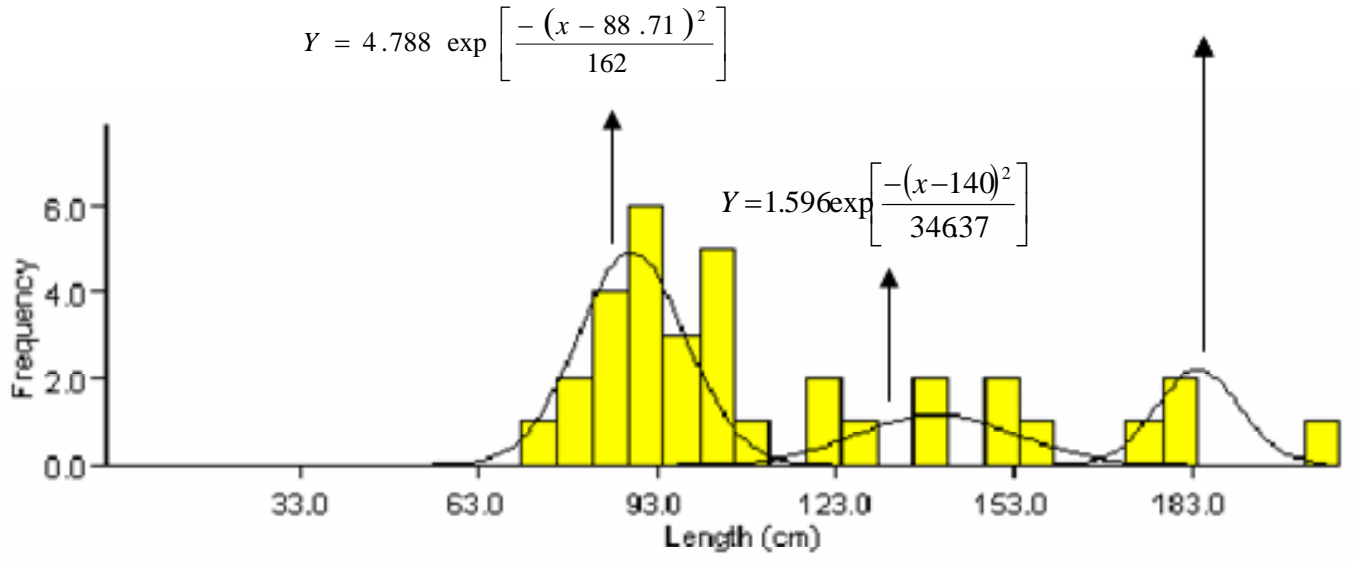

Gambar 4. Kelompok umur ikan semah di perairan Sungai Musi, Sumatera Selatan.

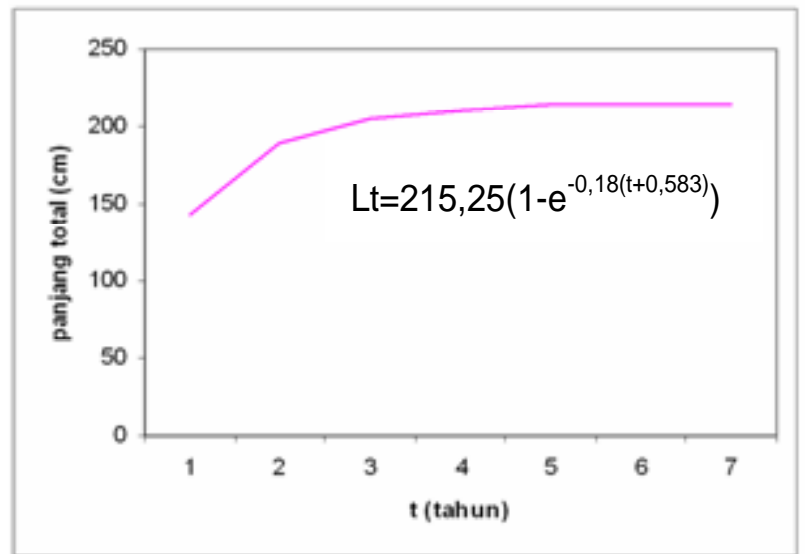

Gambar 5. Pertumbuhan panjang ikan semah di perairan Sungai Musi, Sumatera Selatan. 


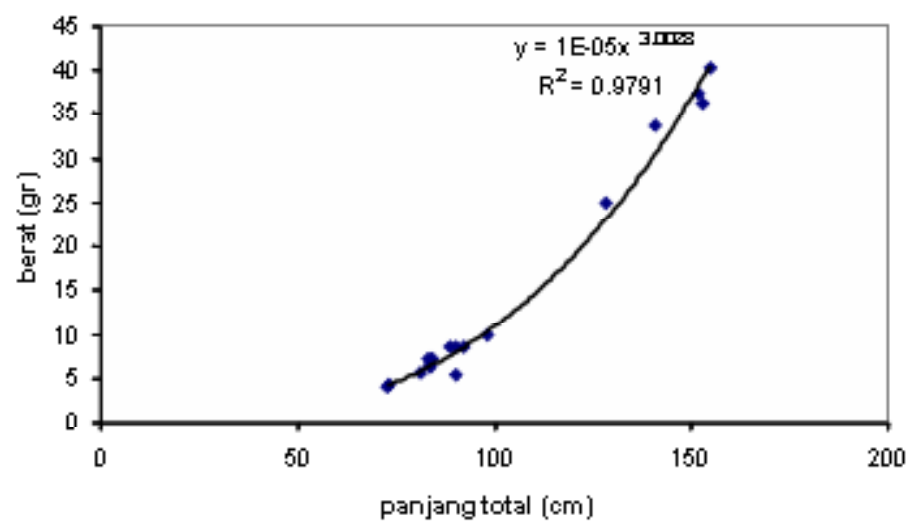

Gambar 6. Hubungan panjang bobot ikan semah di perairan Sungai Musi, Sumtera Selatan.

Gambar 7. Model pertumbuhan bobot ikan semah di perairan Sungai Musi, Sumatera Selatan.

dipengaruhi oleh nilai $\mathrm{k}$. Besaran $\mathrm{k}$ untuk ikan semah adalah 0,16. Menurut Tesch (1971), pada saat ukuran kecil, pertumbuhan ikan meningkat secara lambat, kemudian, laju pertumbuhannya meningkat secara cepat. Setelah kurun waktu tertentu, laju pertumbuhan kembali meningkat dengan lambat sampai akhirnya tetap pada suatu garis asimtotik. Oleh karena itu, menurut Weatherly \& Gill (1987), pengetahuan tentang umur ikan merupakan hal penting untuk mengungkapkan permasalahan daur hidup ikan seperti ketahanan hidup, laju pertumbuhan, dan umur ikan saat matang gonad.

Nilai b dari hubungan panjang bobot ikan semah adalah lebih dari 3,0. Hal ini menunjukkan bahwa pertumbuhan ikan tersebut di perairan Sungai Musi bersifat allometrik positif. Besaran nilai b tergantung kepada sediaan makanan (Le Cren, 1951), tingkat kematangan gonad (Frost, 1945), dan jenis kelamin (Hile \& Jobes, 1940). Hubungan panjang bobot ini menunjukkan pertumbuhan yang bersifat relatif, artinya dapat berubah menurut waktu. Apabila terjadi perubahan lingkungan dan ketersediaan makanan, diperkirakan nilai ini juga akan berubah (Effendie, 1997).
Bobot asimtotik $\left(\mathrm{W}_{\text {maks }}\right)$ ikan semah adalah 43,58 g. Ikan semah diduga mendekati bobot asimtotiknya pada umur 5,5 tahun. Pertambahan bobot yang cepat diperkirakan pada saat ikan mencapai umur 1 - 3 tahun. Informasi ini cukup penting untuk budidaya, khususnya dalam hal pemberian pakan.

Dari persamaan pertumbuhan yang diperoleh di atas dapat diperkirakan panjang ikan ketika lahir (pada saat $\mathrm{t}=0$ ). Panjang dan bobot ikan semah tersebut masing-masing adalah $21,44 \mathrm{~mm}$ dan $0,645 \mathrm{~g}$. Hasil perhitungan bobot larva yang diperkirakan secara matematis perlu dibandingkan dengan kegiatan pemeliharaan sejak larva. Jumlah contoh ikan yang digunakan diduga berpengaruh terhadap perhitungan tersebut. Namun demikian, persamaan pertumbuhan yang dihasilkan dalam penelitian ini merupakan hasil yang menggambarkan kondisi saat ini. Pembacaan umur ikan dengan analisis terhadap sisik dan otolith diperlukan agar pola pertumbuhan yang didapatkan lebih akurat. Misalnya dengan scanning electron microscope untuk membaca annuli pada sisik dan melihat otolith dengan rasio Stronsium/ Calcium $(S R / C a)$. 


\section{KESIMPULAN}

Ikan semah (Tor tambra) di perairan Sungai Musi memiliki pola pertumbuhan allometrik. Ikan ini diperkirakan memiliki panjang dan bobot pada saat lahir ( $\mathrm{t}=0)$ masing-masing adalah 21,44 mm dan 0,645 g. Ikan semah tidak bertambah panjang dan bobotnya masing-masing setelah mencapai 6 dan 5,5 tahun. Pertambahan bobot ikan yang cepat diperkirakan terjadi pada saat ikan mencapai umur 1-3 tahun.

\section{PERSANTUNAN}

Kegiatan dari hasil riset karakteristik habitat dan keanekaragaman jenis ikan semah di Indonesia, T. A. 2008, di Balai Riset Perikanan Peraiaran Umum, Palembang.

\section{DAFTAR PUSTAKA}

Effendie, M. I. 1979. Metode Biologi Perikanan. Yayasan Dewi Sri. Bogor. 112 pp.

1997. Biologi Perikanan. Yayasan Pustaka Nusantara. Yogyakarta. 163 pp.

Frost, W. E. 1945. The age and growth of eels (Anguilla anguilla) from the Windermere catchment area. Part 2. J. Anim. Ecol. 4: 106-124.

Hardjamulia, A., N. Suhenda, B. Muharam, \& E. Wahyudin. 1999. Pengaruh pakan berkadar protein berbeda terhadap terhadap pertumbuhan, laju sintasan, dan perkembangan ovari gelondongan ikan semah (Tor douronensis) di Danau Kerinci dan Sungai Merangin, Jambi. Jurnal Penelitian Perikanan Indonesia. 4: p. 7-14.

Hile, R. \& F. W. Jobes. 1940. Age, growth, and production of the yellow perch. Perca flavescens (Mitchill), of Saginaw Baya. Trans. Am. Fish. Soc. 70:102-122.

Kottelat, M. \& K. K. P. Lim. 1993. A review of the Eel Loaches of the genus Pangio (Teleostei: Cobitidae) from the Malay Peninsula, with descriptions of six new species. Raffles Bulletin of Zoology. 41 (2): 203-249.

Lagler, K. F., J. E. Bardach, R. R. Miller, \& D. R. M. Passino. 1977. Ichthyology (Second Edition). John Wiley \& Sons. New York. 506 pp.
Le Cren, E. D. 1951. The weight length relationship and seasonal cycle in gonad weight and the condition in Perch (Perca fluviatilis). J. Anim. Ecol. 20: 201-219.

Pauly, D. 1988. Fisheries reseach of Southeast Asia In J. A. Gulland (ed.). Fish Population Dynamics (Second Edition). John Wiley \& Sons. New York.

Rachmatika, I. 1992. Tambra, traditionally conserved. Voice of Nature. 89: 56-57.

Ricker, W. E. 1975 Computation and interpretation of biological statistics of fish populations. Bulletin. 19. Ottawa: Department of the Environment, Fisheries, and Marine Service.

Rupawan, A. Karim, \& Husnah. 1999. Beberapa sifat biologi dan ekologi ikan semah (Tor douronensis) di Danau Kerinci dan Sungai Merangin, Jambi. Jurnal Penelitian Perikanan Indonesia. 4: 1-6.

Sparre, P. \& S. C. Venema. 1999. Introduksi Pengkajian Stok Ikan Tropis Buku 1: Manual. FAO dan Badan Penelitian dan Pengembangan Pertanian. Jakarta. 438 pp.

Sabar, F. 1983. Perlindungan ikan tambra (Labeobarbus sp.) di Sumatera Barat. Fauna Indonesia 1. (1):15-16.

Smith, H. M. 1945. The Freshwater Fishes of Siam, or Thailand. Simthsonian Institution. United States National Museum. Bulletin 188. Washington. 593 pp.

Sulastri, I. Rachmatika, \& D. I. Hartoto. 1985. Feeding and reproductive patterns of Tor spp. as a base for its aquaculture. Berita Biologi 3. (3): 84-90.

Tesch, F. W. 1971. Age and growth. In Ricker, W. E. (ed). Method for Assessment of Fish Production in Fresh Waters. Blackwell Scientific Publications. Oxford. p. 98-130.

Weatherley, A. H. \& H. S. Gill. 1987. The Biology of Fish Growth. Academic Press. London.

Weber, M. \& De Beaufort. 1962. The Fishes of the Indo-Australian Archipelago. Leiden. E. J. B. 402 pp. 